\title{
A Common SNP of IL-10 (-1082A/G) is Associated With Increased Risk of Premenopausal Breast Cancer in South Indian Women
}

\author{
Cingeetham Vinod, ${ }^{1}$ Akka Jyothy, Malladi Vijay kumar, ${ }^{2}$ Ramaiyer Raghu Raman, ${ }^{2}$ Prat- \\ ibha Nallari, and Ananthapur Venkateshwari, ${ }^{1, *}$ \\ ${ }_{1}^{1}$ Institute of Genetics and Hospital for Genetic Diseases, Osmania University, Hyderabad, India \\ ${ }^{2} \mathrm{MNJ}$ Institute of Oncology and Regional Cancer Centre, University, Hyderabad, India \\ ${ }^{3}$ Department of Genetics, Osmania University, Hyderabad, India \\ ${ }^{*}$ Corresponding author: Ananthapur Venkateshwari, Institute of Genetics and Hospital for Genetic Diseases, Osmania University, Hyderabad, India. Tel: +91-4023403681, \\ E-mail:venkateshwari@yahoo.com
}

Received: July 6, 2015; Accepted: July 11, 2015

\begin{abstract}
Background: Evading the immune destruction and angiogenesis has been the two hallmarks of cancer. Interleukin-10 (IL-10) is a cytokine with immune suppressing (pro-tumorigenic) and anti-angiogenic (anti-tumorigenic) properties, thus making the role of IL10 in tumorigenesis enigmatic. Previous studies have suggested a critical role of IL10 altered expression in complex process of tumormicroenvironment, co-evolution and tumorigenesis.

Objectives: Evaluating the role of IL10 (-1082A/G) gene promoter polymorphism in breast cancer patients from South India.

Patients and Methods: A case-control study was conducted with a total of 285 individuals, these include 125 histologically confirmed breast cancer patients and 160 age and sex matched controls. Genotypes were determined by allele-specific polymerase chain reaction (ASPCR), followed by agarose gel electrophoresis. Statistical analysis was done to test the significance of results obtained.

Results: Statistical analysis revealed that AA genotype of the Il-10 -1082A/G polymorphism is significantly associated with breast cancer (AA vs. AG: $\chi^{2}=14.46, \mathrm{P}=0.0001432, \mathrm{OR}=2.854,95 \% \mathrm{CI}=1.68-4.849$ ). Up on stratifying subjects based on cancer stage, age at onset, menopausal status, AAgenotype has associated with all the sub groups, except for post-menopausal women. There was no significant association which was observed with respected to hormonal status (ER, PR) and Her2/neu status.

Conclusions: The present study suggests that IL-10 AA genotype as a risk factor in the etiology of breast cancer in the South Indian population.
\end{abstract}

Keywords: Interleukin-10; Polymorphism; Breast Cancer; Allele Specific Polymerase Chain Reaction

\section{Background}

Breast cancer is the most common cancer in women worldwide with $25.1 \%$ of incidence rate and $27 \%$ among Indian women. It has been the leading cause of cancer related deaths among the women worldwide, with mortality rate of $14.7 \%$, but $21.5 \%$ in India. (Globocan project 2012) (1). The etiology of breast cancer is been multi-factorial with various epidemiological attributes in combination with genetic factors. The role of high penetrant genes like BRCA1, BRCA2, PTEN etc. are well established in etiology of breast cancer. However, the role of low penetrant gene variations are much investigated and less established topic. Hence, our study was designed to evaluate the role of low penetrant IL-10 (-1082A/G) promoter polymorphism known for its influence on expression of the IL-10.

Evading the immune destruction is one of the eight hallmarks of cancer (2). Interleukin-10 (IL-10) is a cytokine known for its immune suppression. Normally $\mathrm{T}$ cells, B cells, dendritic cells and monocytes/macro- phages express IL-10 during inflammation (3). IL-10 is abundantly produced by tumor associated macrophages (TAMs) which form a major component of tumor tissue (4). Hence, it is hypothesized that IL-10 might facilitate tumor cells escape immune surveillance. The immunosuppression of IL-10 is through inhibition of cytokine synthesis (TNF, IL-1, chemokine, and IL-12) by the macrophages needed for $\mathrm{T}$ cell activation. However, the exact role of IL-10 is controversial as there is growing evidence of anti-tumorgenic activity of IL10. It is also known that IL-10 down regulates the synthesis of VEGF, IL-1b, TNF- $\alpha$, IL-6, and MMP-9 needed for angiogenesis during tumor progression, exhibiting anti-tumorigenic property (5). TAMs which produce high levels of IL-10 play an essential role in the complex process of tumor-microenvironment co-evolution and tumorigenesis (4). Previous studies have associated IL-10 promoter polymorphisms with its expression patterns, which

Copyright (C) 2015, Iranian Journal of Cancer Prevention. This is an open-access article distributed under the terms of the Creative Commons Attribution-NonCommercial 4.0 International License (http://creativecommons.org/licenses/by-nc/4.0/) which permits copy and redistribute the material just in noncommercial usages, provided the original work is properly cited. 
Vinod C et al.

there are of opinion that the level of expression might influence tumorigenesis (6). Further, our preliminary insilico-analysis on IL 10 promoter polymorphisms have shown an additional transcription factor binding site in IL-10 promoter region due to $-1082 \mathrm{~A} / \mathrm{G}$ polymorphism.

\section{Objectives}

The present study has intended to find the association between -1082A/G (rs1800896) promoter polymorphism in a group of breast cancer patients, and appropriate controls belonging to South India.

\section{Patients and Methods}

The study group of 125 patients with confirmed breast cancer who were referred to the MNJ institute of oncology and regional cancer center, Hyderabad, India. A group of 160, age and sex matched controls with no familial history of cancer were inducted as part of the study. All patients had their disease confirmed with a trucut biopsy followed by ER, PR and HER2/neu status determination.

All patients have undergone an extensive staging workup which included chest X-Rays, ultrasound, mammography, bone scans and CT scans wherever required. The study has approved by the institutional ethics committee. Epidemiological information of patients and controls was obtained through personal interview. Clinicopathological information was collected from the patient case records with oncologist help. An informed consent was taken from all the patients and controls selected for the study prior to drawing the blood samples.

\subsection{Genotyping of Interleukin-10 (-1082 A/G) Poly- morphism}

After taking informed consent, $5 \mathrm{ml}$ of peripheral blood was collected in EDTA vaccutainer from each subject included in the study. Genomic DNA was extracted from peripheral blood leukocytes following salting out method by Lahiri et al. (7). Genotyping was carried out by using the polymerase chain reaction with allele specific primers as described by Abdolrahim-Zadeh et al. (8). The primer sequences for genotyping is shown in Table 1. PCR was performed after standardization of the protocol and each 15 ul reaction mixture tube contained 50ng of template DNA, $0.2 \mu \mathrm{M}$ of each primer, $120 \mu \mathrm{M}$ of dNTP mixture, $1.5 \mathrm{mM}$ of

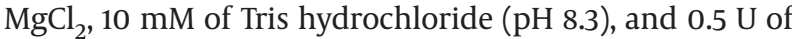
Taq DNA polymerase. PCR conditions for amplification includes an initial melting step of 5 minutes at $95^{\circ} \mathrm{C}$, followed by 25 cycles of 30 seconds at $95^{\circ} \mathrm{C}, 30$ seconds at $63^{\circ} \mathrm{C}, 30$ seconds at $72^{\circ} \mathrm{C}$ and a final elongation at $72^{\circ} \mathrm{C}$ for 5 minutes. The amplified products was run on $1.5 \%$ agarose gel, and then stained with ethidium bromide for visualization under ultraviolet gel documentation system.
Table 1. Allele Specific Primers for IL-10 -1082A/G Promoter Polymorphism

\begin{tabular}{lc}
\hline Primers & \multicolumn{1}{c}{ Sequences } \\
\hline Common primer & 5'-CAGCCCTTCCATTTTACTTTC-3' \\
G allele primer & 5'-TACTAAGGCTTCTTTGGGAG-3' \\
A allele primer & 5'-CTACTAAGGCTTCTTTGGGAA-3' \\
\hline
\end{tabular}

The genotype results have reconfirmed by performing genotyping twice in randomly selected $10 \%$ of the subjects and the results were in $100 \%$ concordance.

\subsection{Statistical Analysis}

Statistical significance for the differences in the allele, genotype frequencies of the studied polymorphism between cases and healthy controls was determined by the Yates corrected $\chi^{2}$ test. The Odds ratio for genotype frequencies between the cases and the controls were also determined. All the P Values were two sided, and the level of significance was taken as $\mathrm{P}<0.05$. Further, prediction of transcription factors binding to promoter region was performed using Alibaba 2, an online bioinformatic tool.

\section{Results}

The genotype and allele frequency distribution of IL-10 $-1082 \mathrm{~A} / \mathrm{G}$ promoter polymorphism in 125 breast cancer patients and 160 controls were shown in Table 2. HardyWeinberg equilibrium for IL-10 -1082 A/G polymorphism in breast cancer group have shown a significant deviation $\left(\chi^{2}=16.92\right)$ and no significant deviation was found among controls $\left(\chi^{2}=1.3\right)$. In the present study, IL-10 -1082AA genotype frequency was significantly elevated among breast cancer cases $(\mathrm{P}=0.0001432)$ compared to controls under codominant model of inheritance. Further, the codominant model has revealed the existence of a statistically significant association between major genotype (AA) and breast cancer (AA vs. AG: $\chi^{2}=14.46$, $\mathrm{P}=0.0001432, \mathrm{OR}=2.854,95 \% \mathrm{CI}=1.68-4.849)$. Further dominant (AG+GG vs. AA: $\chi^{2}=9.311, \mathrm{P}=0.002278$, $\mathrm{OR}=2.153,95 \% \mathrm{CI}=1.336-3.469$ ) and over dominant (AG vs. $\mathrm{AA}+\mathrm{GG}: \chi^{2}=16.04, \mathrm{P}=0.00006189, \mathrm{OR}=2.884,95 \% \mathrm{CI}$ $=1.731$ - 4.807) inheritance models have also supported the association of AA genotype with about 2.8 times of increased risk in breast cancer patients. It was also seen that there was a border line significant difference in allele distribution, among the patients and controls, both. (A vs. G: $\chi^{2}=2.868, \mathrm{P}=0.09037, \mathrm{OR}=1.391,95 \% \mathrm{CI}=$ $0.9676-2.001)$. 
The patient group was classified into early (includes stage I and II) and late stages (includes stage III and IV), less than 40 and greater than 40 age at onset, pre and post-menopausal patients to evaluate the association of different clinic pathological and epidemiological factors with breast cancer. The difference in genotypic distribution of IL-10 (-1082A/G) polymorphism was statistically significant in both early stage (Table 3) (AA vs. AG: $\chi^{2}=5.387, \mathrm{P}=0.02029, \mathrm{OR}=2.507,95 \% \mathrm{CI}$ $=1.203-5.226$ ) and late stage patients (Table 3) (AA vs. AG: $\chi^{2}=10.11, P=0.001478, O R=3.493,95 \% C I=1.639$ 7.441). In comparison with controls there was a one fold increased risk in later stage patients with IL-10 -1082AA genotype than early stage patients. Similarly there was statistically significant increased risk in both $<40$ years (Table 4) (AA vs. AG: $\chi^{2}=11.12, P=0.0008525, \mathrm{OR}=$ $6.071,95 \% \mathrm{CI}=2.169-16.99)$ and $>40$ year age of onset groups (Table 4 ) (AA vs. AG: $\chi^{2}=4.943, \mathrm{P}=0.02620, \mathrm{OR}=$ $2.143,95 \% \mathrm{CI}=1.139-4.032)$, but it was found that there was about 4 folds increased risk in patients effected with breast cancer before 40 years of age. Our results have also revealed that IL-10 -1082AA genotype of premenopausal women (Table 5) (AA vs. AG: $\chi^{2}=8.608, \mathrm{P}$ $=0.003347, \mathrm{OR}=4.883,95 \% \mathrm{CI}=1.757$ - 13.57) was significantly associated with increased risk $\chi^{2}$ of breast cancer, although there was no association between genotype distribution and post-menopausal women (Table 5) (AA vs. $\mathrm{AG}: \chi^{2}=2.471, \mathrm{P}=0.1160, \mathrm{OR}=1.797,95 \% \mathrm{CI}=$ 0.9256 - 3.489; AA vs. GG: $=0.004773, \mathrm{P}=0.9449, \mathrm{OR}=$ $0.9231,95 \% \mathrm{CI}=0.3629-2.348)$. Further the distribution of genotypes was classified based on estrogen receptor status (ER) (AA vs. AG: $\chi^{2}=0.4566, P=0.4992, \mathrm{OR}=0.5758$, 95\% $\mathrm{CI}=0.1855-4.849)$, progesterone receptor status (PR) (AA vs. AG: $\chi^{2}=0.08056, P=0.7765, \mathrm{OR}=0.7238,95 \%$ $\mathrm{CI}=0.2367-2.213$ ), and Her2/neu status (AA vs. AG: $\chi^{2}=$ $1.246, \mathrm{P}=0.2642, \mathrm{OR}=0.3143,95 \% \mathrm{CI}=0.06603-1.496)$, has revealed no significant variation in the distribution of $-1082 \mathrm{~A} / \mathrm{G}$ polymorphism of IL-10.

Table 2. Distribution of Genotypes and Allele Frequencies of IL-10 (A-1082 G) Promoter Polymorphism in Breast Cancer Patients and Controls

\begin{tabular}{lccccc}
\hline Genotype & Disease $\mathbf{N}=\mathbf{1 2 5}$ & Control N=160 & $\chi^{2}$ & P Value & OR (95\% CI $)$ \\
\hline Co-dominant & & & & & \\
\hline AA & $76(60.8)$ & $67(41.875)$ & ref & & $2.854(1.68-4.849)$ \\
\hline AG & $31(24.8)$ & $78(48.75)$ & 14.46 & $0.00014^{\mathrm{a}}$ & $0.945(0.4422-2.021)$ \\
\hline GG & $18(14.4)$ & $15(9.375)$ & 0.002342 & 0.9614 & \\
\hline
\end{tabular}

Allele

\begin{tabular}{|c|c|c|c|c|c|}
\hline A & $183(73.2)$ & $212(66.25)$ & & & \\
\hline G & $67(26.8)$ & $108(33.75)$ & 2.868 & 0.0903 & $1.391(0.967-2.001)$ \\
\hline \multicolumn{6}{|c|}{ Dominant } \\
\hline AA & $76(60.8)$ & $67(41.875)$ & & & \\
\hline $\mathrm{AG}+\mathrm{GG}$ & $49(39.2)$ & $93(58.125)$ & 9.311 & $0.0022^{\mathrm{a}}$ & $2.153(1.336-3.469)$ \\
\hline
\end{tabular}

Recessive

\begin{tabular}{lccccc}
\hline AA + AG & $107(85.6)$ & $145(90.625)$ & & & \\
\hline GG & $18(14.4)$ & $15(9.375)$ & 1.275 & 0.2598 & \\
\hline Over dominant & & & & & \\
\hline AA + GG & $94(75.2)$ & $82(51.25)$ & & $0.2966-1.275)$ \\
\hline AG & $31(24.8)$ & $78(48.75)$ & 16.04 & $0.00006^{\text {a }}$ & $2.884(1.731-4.807)$ \\
\hline
\end{tabular}

a $\mathrm{P} \leq 0.05$. 
Vinod C et al.

Table 3. Distribution of Genotypes and Allele Frequencies of IL-10 (A-1082 G) Promoter Polymorphism With Respect to Early Stage and Late Stage Breast Cancer

\begin{tabular}{|c|c|c|c|c|c|c|c|c|}
\hline \multirow[t]{2}{*}{ Genotype } & \multicolumn{4}{|c|}{ Early Stage Breast Cancer } & \multicolumn{4}{|c|}{ Late Stage Breast Cancer } \\
\hline & $\begin{array}{l}\text { Disease } \\
(\mathrm{N}=\mathbf{4 6})\end{array}$ & $\begin{array}{c}\text { Control } \\
(\mathbf{N}=160)\end{array}$ & $\begin{array}{c}\text { P Value } \\
\chi^{2}\end{array}$ & OR $(95 \% \mathrm{CI})$ & $\begin{array}{l}\text { Disease } \\
(\mathrm{N}=\mathbf{5 2})\end{array}$ & $\begin{array}{c}\text { Control } \\
(\mathbf{N}=160)\end{array}$ & $\begin{array}{c}\text { PValue } \\
\chi^{2}\end{array}$ & OR $(95 \% \mathrm{CI})$ \\
\hline \multicolumn{9}{|c|}{ Co-Dominant } \\
\hline $\mathrm{AA}$ & $28(60.86)$ & $67(41.87)$ & & & $33(63.46)$ & $67(41.87)$ & & \\
\hline AG & $13(28.26)$ & $78(48.75)$ & $0.02029^{a}$ & $2.507(1.203-5.226)$ & $11(21.15)$ & $78(48.75)$ & $0.0014^{a}$ & $3.493(1.639-7.441)$ \\
\hline GG & $5(10.86)$ & $15(9.375)$ & 0.896 & $1.254(0.415-3.781)$ & $8(15.38)$ & $15(9.375)$ & 0.9348 & $0.9235(0.355-2.397)$ \\
\hline \multicolumn{9}{|l|}{ Allele } \\
\hline A & $69(75.0)$ & $212(66.25)$ & & & $77(74.03)$ & $212(66.25)$ & & \\
\hline G & $23(25.0)$ & $108(33.75)$ & 0.144 & $1.528(0.903-2.585)$ & $27(25.96)$ & $108(33.75)$ & 0.174 & $1.453(0.884-2.385)$ \\
\hline \multicolumn{9}{|l|}{ Dominant } \\
\hline $\mathrm{AA}$ & $28(60.86)$ & $67(41.87)$ & & & $33(63.46)$ & $67(41.87)$ & & \\
\hline $\mathrm{AG}+\mathrm{GG}$ & $18(39.13)$ & $93(58.12)$ & $0.03488^{\mathrm{a}}$ & $2.159(1.105-4.221)$ & $19(36.53)$ & $93(58.12)$ & $0.0108^{a}$ & $2.411(1.264-4.599)$ \\
\hline \multicolumn{9}{|l|}{ Recessive } \\
\hline $\mathrm{AA}+\mathrm{AG}$ & $41(89.13)$ & $145(90.62)$ & & & $44(84.61)$ & $145(90.62)$ & & \\
\hline GG & $5(10.86)$ & $15(9.375)$ & 0.9847 & $0.848(0.291-2.473)$ & $8(15.38)$ & $15(9.37)$ & & $0.569(0.226-1.43)$ \\
\hline \multicolumn{9}{|c|}{ Over Dominant } \\
\hline $\mathrm{AA}+\mathrm{GG}$ & $33(71.74)$ & $82(51.25)$ & & & $41(78.84)$ & $82(51.25)$ & & \\
\hline AG & $13(28.26)$ & $78(48.75)$ & $0.02158^{\mathrm{a}}$ & $2.415(1.184-4.925)$ & $11(21.15)$ & $78(48.75)$ & $0.0008^{a}$ & $3.545(1.702-7.388)$ \\
\hline
\end{tabular}

$\mathrm{a} \mathrm{P} \leq 0.05$

Table 4. Distribution of Genotypes and Allele Frequencies of IL-10 (A-1082 G) Promoter Polymorphism in Breast Cancer Patients with Age at Onset $<40$ and $>40$ Years and Age Matched Controls

\begin{tabular}{|c|c|c|c|c|c|c|c|c|}
\hline \multirow[t]{2}{*}{ Genotype } & \multicolumn{4}{|c|}{ Age at Onset $<40$} & \multicolumn{4}{|c|}{ Age at Onset $>40$} \\
\hline & $\begin{array}{l}\text { Disease } \\
(\mathrm{N}=46)\end{array}$ & $\begin{array}{c}\text { Control } \\
(\mathbf{N}=160)\end{array}$ & $\begin{array}{c}\text { PValue } \\
\chi^{2}\end{array}$ & OR $(95 \% \mathrm{CI})$ & $\begin{array}{l}\text { Disease } \\
(\mathrm{N}=52)\end{array}$ & $\begin{array}{l}\text { Control } \\
(\mathbf{N}=160)\end{array}$ & $\begin{array}{c}\text { P Value } \\
\chi^{2}\end{array}$ & $\mathrm{OR}(95 \% \mathrm{CI})$ \\
\hline \multicolumn{9}{|c|}{ Co-Dominant } \\
\hline $\mathrm{AA}$ & $20(58.82)$ & $14(26.92)$ & & & $56(61.53)$ & $50(47.61)$ & & \\
\hline AG & $8(23.52)$ & $34(65.38)$ & $0.0008^{a}$ & $6.071(2.169-16.99)$ & $23(25.27)$ & $44(41.90)$ & 0.0262 & $2.143(1.139-4.032)$ \\
\hline GG & $6(17.64)$ & $4(7.69)$ & 0.7647 & $0.9524(0.226-4.01)$ & $12(13.18)$ & $11(10.47)$ & 0.8625 & $1.027(0.416-2.532)$ \\
\hline \multicolumn{9}{|l|}{ Allele } \\
\hline A & $48(70.58)$ & $62(59.61)$ & & & $135(74.17)$ & $144(68.57)$ & & \\
\hline G & $20(29.41)$ & $42(40.38)$ & 0.1928 & $1.626(0.846-3.121)$ & $47(25.82)$ & $66(31.42)$ & 0.2681 & $1.316(0.846-2.047)$ \\
\hline Dominant & & & & & $56(61.53)$ & $50(47.61)$ & & \\
\hline $\mathrm{AA}$ & $20(58.82)$ & $14(26.92)$ & & & $35(38.46)$ & $55(52.38)$ & $0.07084^{b}$ & $1.76(0.995-3.112)$ \\
\hline$A G+G G$ & $14(41.17)$ & $38(73.07)$ & $0.0062^{\mathrm{a}}$ & $3.878(1.549-9.706)$ & & & & \\
\hline Recessive & & & & & $79(86.81)$ & $94(89.52)$ & & \\
\hline $\mathrm{AA}+\mathrm{AG}$ & $28(82.35)$ & $48(92.30)$ & & & $12(13.18)$ & $11(10.47)$ & 0.7147 & $0.770(0.322-1.841)$ \\
\hline GG & $6(17.64)$ & $4(7.69)$ & 0.2887 & $0.3889(0.101-1.497)$ & $56(61.53)$ & $50(47.61)$ & & \\
\hline \multicolumn{9}{|c|}{ Over Dominant } \\
\hline $\mathrm{AA}+\mathrm{GG}$ & $26(76.47)$ & $18(34.61)$ & & & $68(74.72)$ & $61(58.09)$ & & \\
\hline AG & $8(23.52)$ & $34(65.38)$ & $0.0003^{\mathrm{a}}$ & $6.139(2.311-16.31)$ & $23(25.27)$ & $44(41.90)$ & $0.02162^{\mathrm{a}}$ & $2.133(1.157-3.93)$ \\
\hline
\end{tabular}


Vinod C et al.

Table 5. Distribution of Genotypes and Allele Frequencies of IL-10 (A-1082 G) Promoter Polymorphism in Premenopausal Breast Cancer Patients, Versus Premenopausal Controls and Postmenopausal Breast Cancer Patients Versus Postmenopausal Controls

\begin{tabular}{|c|c|c|c|c|c|c|c|c|}
\hline \multirow[t]{2}{*}{ Genotype } & \multicolumn{4}{|c|}{ Premenopausal } & \multicolumn{4}{|c|}{ Postmenopausal } \\
\hline & $\begin{array}{l}\text { Disease } \\
(N=46)\end{array}$ & $\begin{array}{c}\text { Control } \\
(\mathrm{N}=160)\end{array}$ & $\begin{array}{c}\chi^{2} \mathbf{P} \\
\text { Value }\end{array}$ & OR (95\% CI $)$ & $\begin{array}{l}\text { Disease } \\
(\mathrm{N}=52)\end{array}$ & $\begin{array}{c}\text { Control } \\
(\mathrm{N}=160)\end{array}$ & $\begin{array}{c}\chi^{2} \mathbf{P} \\
\text { Value }\end{array}$ & OR $(95 \% \mathrm{CI})$ \\
\hline \multicolumn{9}{|c|}{ Co-Dominant } \\
\hline AA & $16(57.14)$ & $22(29.33)$ & & & $60(62.5)$ & $45(52.94)$ & & \\
\hline$A G$ & $7(25)$ & $47(62.66)$ & $0.0033^{\mathrm{a}}$ & $4.883(1.757-13.57)$ & $23(23.95)$ & $31(36.47)$ & 0.116 & $1.797(0.925-3.489)$ \\
\hline GG & $5(17.85)$ & $6(8)$ & 0.8821 & $0.8727(0.226-3.367)$ & $13(13.54)$ & $9(10.58)$ & 0.9449 & $0.923(0.362-2.348)$ \\
\hline \multicolumn{9}{|l|}{ Allele } \\
\hline A & $39(69.64)$ & $91(60.66)$ & & & $143(74.4)$ & $121(71.17)$ & & \\
\hline G & $17(30.35)$ & $59(39.33)$ & 0.3069 & $1.487(0.771-2.869)$ & $49(25.5)$ & $49(28.82)$ & 0.557 & $1.182(0.743-1.88)$ \\
\hline \multicolumn{9}{|l|}{ Dominant } \\
\hline $\mathrm{AA}$ & $16(57.14)$ & $22(29.33)$ & & & $60(62.5)$ & $45(52.94)$ & & \\
\hline $\mathrm{AG}+\mathrm{GG}$ & $12(42.85)$ & $53(70.66)$ & $0.0176^{*}$ & $3.212(1.308-7.888)$ & $36(37.5)$ & $40(47.06)$ & 0.2511 & $1.481(0.818-2.682)$ \\
\hline \multicolumn{9}{|l|}{ Recessive } \\
\hline $\mathrm{AA}+\mathrm{AG}$ & $23(82.14)$ & $69(92)$ & & & $83(86.45)$ & $76(89.41)$ & & \\
\hline GG & $5(17.8)$ & $6(8)$ & 0.2803 & $0.4(0.1115-1.435)$ & $13(13.54)$ & $9(10.58)$ & 0.7047 & $0.756(0.305-1.869)$ \\
\hline \multicolumn{9}{|c|}{ Over Dominant } \\
\hline $\mathrm{AA}+\mathrm{GG}$ & $21(75)$ & $28(37.33)$ & & & $73(76.04)$ & $54(63.52)$ & & \\
\hline AG & $7(25)$ & $47(62.66)$ & 10.14 & $0.0014^{\mathrm{a}}$ & $23(23.96)$ & $31(36.47)$ & $0.0942^{b}$ & $1.82(0.957-3.469)$ \\
\hline
\end{tabular}

a $\mathrm{P} \leq 0.05$.

b $\mathrm{P} \geq 0.05-<0.10$ (borderline significant).

\section{Discussion}

In the previous studies it was seen that around $5 \%-10 \%$ of breast cancers are inherited and the remaining were sporadic (9-11). For above relation, about $25 \%-30 \%$ of familial breast cancers are attributed to genes like BRCA1, BRCA2, PTEN, CHEK2, BACH1, PALB2, RAD50, TP53 etc., these have known as highly or moderately penetrant genes $(12,13)$. However, there is a growing need to screen variations in low penetrant genes and establish its role in disease development. Evading immune destruction is an emerging hall mark of cancer, as highly immunogenic cancer cells might well evade immune destruction by disabling components of the immune system that have been dispatched to eliminate them (2). In this regard, we chose to select IL-10, a cytokine that suppressed immune responses. IL-10 gene was mapped to"1q31-1q32" (14). IL-10 exerts immune suppression activity, by down regulating the expression of surface co-stimulatory molecules like CD80 or CD86 on tumor cells, thus preventing antigen presenting cells (APC) from obtaining access to tumor antigen (15).

The present study evaluated the association between IL10-A1058G promoter polymorphism and breast cancer in the South Indian population. The statistical analysis has revealed a significant increased risk of breast cancer with low IL-10 expressing AA genotype which is been in concordance with other studies in Italian and Austrian populations (Giordani et al. 2003) (16), (Langsenlehner et al. 2005) (17). However, our results are in contrast with other population studies by Howell et al. (England) (18), Smith et al. (England) (19), Balasubramanian et al. (England) (20), Kong et al. (Chinese) (21) and Abdolrahim-Zadeh et al. (Iranian) (8), respectively. These contrasting results may be attributed to ethnic difference and haplotype variations or linkage disequilibrium with other polymorphisms in its proximity. Kang et al (2010) have determined: that A allele of IL-10 A-1082G promoter region physically interacted with a nuclear protein poly (ADPribose) polymerase1 (PARP-1) in allele specific manner that has resulted in differential expression of IL-10. As the -1082A binds to PARP-1in greater extent than G allele, the former has lesser transcription activity than latter (22). In silico analysis was performed to predict transcriptional factors binding to IL-10 promoter region using Alibaba 2.1 (Grabe 2002) online bioinformatics tool, and then found a change in $-1082 \mathrm{~A}-\mathrm{G}$ created an additional transcription binding site for Krox-20 beside Sp1. This additional potential of $\mathrm{G}$ allele to bind krox-20 might play a role in higher expression of IL-10 (23).

In contrast to anti-tumorigenic properties of IL-10, Simone et al. 2005), has reviewed that high levels of IL-10 in tumor microenvironment might favor in the immunemediated tumor rejection by increasing NK cell activity, and then enhancing cytotoxicity and migration of CTL (24). This opinion was helped us in hypothesizing possible role of IL-10 A -1082G polymorphism in breast cancer. Previous studies have correlated higher level of IL-10 expression with $-1082 \mathrm{G}$ allele, which was also associated with protection against breast cancer. As AA genotype 
is associated with low levels of IL-10 expression, the produced amount of IL-10 might to be insufficient to induce immune mediated tumor rejection. Thus justifying its association with an increased breast cancer risk.

The patients were stratified into early and late cancers based on TNM scoring. The AA genotype correlated with both early and later stages of cancer. There was one fold increased risk of developing breast cancer in the patients who have presented with advanced stage in comparison with those who have presented in early stages. This increased risk might be attributed to increase in number of TAM cells with advancement of cancer. The analysis has also revealed that AA genotype, is associated with an increased risk of breast cancer in pre-menopausal women. In contrast, Singh et al. (2012) has found an association with postmenopausal women in North Indian population. Based on age at onset, the patients were stratified into age groups of below and above 40 years. Both groups were associated with AA genotype. There was fourfold increased risk in the age group below 40 years. As IL10 levels are low in younger than elder people, the younger patients with low expressing AA genotype might further increase the risk of breast cancer. There was no correlation between genotype or allele frequency distribution, and hormonal receptor status (ER, PR), and Her2 which has been in concurrence to other studies (17). Although in Iranian population, an increase AA genotype frequency was seen in PR negative patients (8).

There was a statistically significant correlation between the AA genotype of -A1082 G gene promoter polymorphism, with an increased risk of breast cancer in a cohort from South India. However, further studies with larger sample size, and haplotype analysis with other promoter variants are required providing further evidences to establish the role of this polymorphism in breast cancer.

\section{Acknowledgement}

The authors would like to thank Department of Biotechnology (DBT-OU-ISLARE ) New Delhi for financial support.

\section{Authors Contribution}

Cingeetham Vinod contributed in genotyping, data analysis and redaction of the manuscript. Akka Jyothy and Prathibha Nallari contributed to the organization and realization of the study, Malladi Vijay Kumar and Ramaiyar Raghu Raman clinically diagnosed breast cancer patients and provided clinicopathological data and reviewed the manuscript. A.Venkateshwari Conception of the study.

\section{Conflicts of Interest}

The authors declare that there are no conflicts of interest.

\section{Financial Disclosure}

There is no financial disclosure.

\section{References}

1. Ferlay J, Soerjomataram I, Dikshit R, Eser S, Mathers C, Rebelo $\mathrm{M}$, et al. Cancer incidence and mortality worldwide: sources, methods and major patterns in GLOBOCAN 2012. Int J Cancer. 2015;136(5):E359-86.

2. Hanahan D, Weinberg RA. Hallmarks of cancer: the next generation. Cell. 2011;144(5):646-74.

3. de Waal Malefyt R, Yssel H, Roncarolo MG, Spits H, de Vries JE. Interleukin-10. Curr Opin Immunol. 1992;4(3):314-20.

4. Wang R, Lu M, Zhang J, Chen S, Luo X, Qin Y, et al. Increased IL-10 mRNA expression in tumor-associated macrophage correlated with late stage of lung cancer. J Exp Clin Cancer Res. 2011;30:62.

5. Huang S, Ullrich SE, Bar-Eli M. Regulation of tumor growth and metastasis by interleukin-10: the melanoma experience. J Interferon Cytokine Res. 1999;19(7):697-703.

6. Turner DM, Williams DM, Sankaran D, Lazarus M, Sinnott PJ Hutchinson IV. An investigation of polymorphism in the interleukin-10 gene promoter. Eur J Immunogenet. 1997;24(1):1-8.

7. Lahiri DK, Nurnberger JJ. A rapid non-enzymatic method for the preparation of HMW DNA from blood for RFLP studies. Nucleic Acids Res. 1991;19(19):5444.

8. Abdolrahim-Zadeh H, Hakkakian N, Asadollahi R, Gharesifard B, Sarvari J, Kamali-Sarvestani E, et al. Interleukin-10 Promoter Polymorphisms and Breast Cancer Risk in Iranian Women. IJI 2005;2(3):158-65.

9. Claus EB, Schildkraut JM, Thompson WD, Risch NJ. The genetic attributable risk of breast and ovarian cancer. Cancer 1996;77(11):2318-24.

10. Narod SA, Foulkes WD. BRCA1 and BRCA2: 1994 and beyond. Nat Rev Cancer. 2004;4(9):665-76.

11. Parkin DM. International variation. Oncogene. 2004;23(38):6329-40.

12. Easton DF. How many more breast cancer predisposition genes are there? Breast Cancer Res. 1999;1(1):14-7.

13. Antoniou AC, Easton DF. Models of genetic susceptibility to breast cancer. Oncogene. 2006;25(43):5898-905.

14. Eskdale J, Kube D, Tesch H, Gallagher G. Mapping of the human IL10 gene and further characterization of the 5 ' flanking sequence. Immunogenetics. 1997;46(2):120-8.

15. Beissert S, Hosoi J, Grabbe S, Asahina A, Granstein RD. IL-10 inhibits tumor antigen presentation by epidermal antigen-presenting cells. JImmunol. 1995;154(3):1280-6.

16. Giordani L, Bruzzi P, Lasalandra C, Quaranta M, Schittulli F, Della Ragione F, et al. Association of breast cancer and polymorphisms of interleukin-10 and tumor necrosis factor-alpha genes. Clin Chem. 2003;49(10):1664-7.

17. Langsenlehner U, Krippl P, Renner W, Yazdani-Biuki B, Eder T, Koppel H, et al. Interleukin-10 promoter polymorphism is associated with decreased breast cancer risk. Breast Cancer Res Treat. 2005;90(2):113-5

18. Howell WM, Rose-Zerilli MJ. Interleukin-10 polymorphisms, cancer susceptibility and prognosis. Fam Cancer. 2006;5(2):143-9.

19. Smith KC, Bateman AC, Fussell HM, Howell WM. Cytokine gene polymorphisms and breast cancer susceptibility and prognosis. EurJ Immunogenet. 2004;31(4):167-73.

20. Balasubramanian SP, Azmy IA, Higham SE, Wilson AG, Cross SS, Cox A, et al. Interleukin gene polymorphisms and breast cancer: a case control study and systematic literature review. BMC Cancer. 2006;6:188.

21. Kong F, Liu J, Liu Y, Song B, Wang H, Liu W. Association of interleukin-10 gene polymorphisms with breast cancer in a Chinese population.J Exp Clin Cancer Res. 2010;29:72.

22. Kang X, Kim HJ, Ramirez M, Salameh S, Ma X. The septic shock-associated IL-10 -1082 A > G polymorphism mediates allele-specific transcription via poly(ADP-Ribose) polymerase 1 in macrophages engulfing apoptotic cells. I Immunol. 2010;184(7):3718-24.

23. Ursing BM, van Enckevort FH, Leunissen JA, Siezen RJ. EXProt--a database for EXPerimentally verified Protein functions. In Silico Biol. 2002;2(1):1-4.

24. Mocellin S, Marincola FM, Young HA. Interleukin-10 and the immune response against cancer: a counterpoint. J Leukoc Biol. 2005;78(5):1043-51. 